\title{
A study to assess the computer related ergonomic practices and computer related health problems among the final year postgraduate nursing students in selected Colleges Of Nursing, Kolkata, West Bengal.
}

\author{
Porimita Moran \\ BSN, MSN, Staff nurse at Oil India limited Hospital, Duliajan, Dibrugarh \\ DOI: 10.29322/IJSRP.10.03.2020.p9935 \\ http://dx.doi.org/10.29322/IJSRP.10.03.2020.p9935
}

\begin{abstract}
A non experimental, survey research design study was undertaken to assess the computer related ergonomic practices and computer related health problems, among the final year postgraduate nursing students in selected colleges of nursing. The main objective is to findout the computer related health problem and to find out the association between computer related ergonomic practices and computer related health problems. The theoretical framework of the study is based on health belief model. Total 60 final year post graduate nursing student was selected by convenient sampling technique.

The finding of the study revealed that $31.67 \%$ of the student had good computer related ergonomic practice and $65 \%$ of the student had moderate musculoskeletal problem $61.6 \%$ had eye problem and $96.67 \%$ had mild skin problem. Statistically significant associations were found between computer related health problem and type of computer device at 0.05 level of significance.
\end{abstract}

Index Terms- computer, ergonomics, health problems, students.

\section{INTRODUCTION}

$\mathrm{T}$ The word ergonomics is derived from greek words, ergo and nomos meaning work and law. International association describes it as the engineering science dealing with various anatomical, physiological, psychological and engineering philosophies and their interaction with people. ${ }^{(1)}$

Computers are an integral part of life and no longer need specialized training for use. dependence of computers is increasing and has led to health concern. In the absence of a good ergonomic design, extended work for prolonged periods and adversely affect not only vision, but also the muscles of neck, back, shoulders and arms, leading to visual and muscular fatigue and discomfort musculoskeletal condition.

Cartre et al. has reported the association between prolonged computer uses, poor postures at workstations is the main cause of musculoskeletal disorder. (2) Globally the number of people suffering from musculoskeletal conditions has increased by $25 \%$ percent over the past decade and these conditions make $2 \%$ of the global disease burden.
Computers are man- made machine but today men are slaves of it. If we send 4-5 hours on computer we start fleeing tired, sleepy, neck aches, back aches, eye problems and what not.

India, the incidence rate shows that the computer related morbidity was resent in $93 \%$ of the study subjects. The visual problem were seen in $76 \%$ and musculoskeletal in $77.5 \%$ while $35 \%$ felt stressful symptoms. (3) the post graduate nursing students are supposed to spend a considerable amount of time before computer such like preparing assignments, class presentations and the submission of research project which demand the use of computer a lot.

Objectives of the study

1. To identify the computer related ergonomics being practiced by the final year post graduate nursing student.

2. To find out the computer related health problems among the final year post graduate nursing students.

3. To examine the co-relation between computer related ergonomics practices and computer related health problems.

4. To find out the associations between the computer related ergonomics practices and the selected demographic variables

5. To find out association between computer related health problems and the selected demographic variables.

\section{METHODOLOGY}

A non-experimental, descriptive survey design . The study was conducted in CON, medical college and hospital; CON Nrs medical college and hospital and BM Birla college of nursing. the sample size is 60 and the sampling technique was adopted was non-probability convenience sampling.

Description of the tool

Three tools were used for data collection

1. Tool I a semi structured questionnaire schedule (Demographic data), it was collected by interviewing the samples and it consists of age, any computer course undertaken, duration of working days on computer per week, duration of working hours on computer per day, 
whether heard about computer related physical health hazards, type of computer device used, placement of the computer, whether help from other personnel is sought for submitting the computerizes assignment in time.

2. Tool II A semi structured questionnaire of 22 items to assess the computer related ergonomic practices, the minimum score is 0 and maximum is 22 was collected by questioning. An arbiter categorization was made for excellent practice with a score of more than $80 \%$ i.e. $>18$, Good practice with score $71-80 \%$ i.e. $16-18$, fair practice with score $61-71 \%$ i.e. $14-15$, average practice with score $51-60 \%$ i.e. 11-13 and poor practice with score less than $50 \%$ i.e. $<11$.

3. Tool III A semi structured interview schedule of 22 items to assess the computer related health problems among the students, minimum score is 22 and maximum is 66 by interviewing. An arbiter categorization was made for mild i.e. 22-36, moderate i.e. 37-51, severe i.e. 57-66

\section{RESULTS}

Section I: Findings related to demographic variables

Table 1: Frequency and percentage distribution of demographic variables

$$
\mathbf{n}=60
$$

\begin{tabular}{|c|c|c|}
\hline $\begin{array}{l}\text { Demographic } \\
\text { variables }\end{array}$ & Frequency & Percentage \\
\hline \multicolumn{3}{|l|}{ Age in years } \\
\hline $24-34$ & 44 & 73.33 \\
\hline $35-45$ & 12 & 20 \\
\hline $46-56$ & 4 & 6.67 \\
\hline $\begin{array}{l}\text { Computer } \\
\text { undertaken }\end{array}$ & course & \\
\hline Yes & 10 & 16.67 \\
\hline No & 50 & 83.33 \\
\hline
\end{tabular}

Whether heard about

computer related

physical health

hazards

$\begin{array}{lll}\text { Yes } & 53 & \mathbf{8 8 . 3 3} \\ \text { No } & 7 & 11.67\end{array}$

$\begin{array}{lll}\text { No } & 7 & 11.67\end{array}$

\begin{tabular}{lrrr}
\hline $\begin{array}{l}\text { Average } \\
\text { week days }\end{array}$ spent & $\begin{array}{c}\text { per } \\
\text { in }\end{array}$ & \\
computer & & & \\
$<5$ days per week & & 21 & $35 \%$ \\
$\geq 5$ days per week & & 39 & $\mathbf{6 5 \%}$ \\
& & & \\
\hline
\end{tabular}

Average hours per day

spent in computer

2-4 hrs

5-7 hrs $\quad 32 \quad \mathbf{5 3 . 3 3 \%}$

8-10 hrs $\quad 21 \quad 35 \%$

$7 \quad 11.67 \%$

Type of computer used

Laptop

$\begin{array}{llll}\text { Desktop } & & 47 & \mathbf{7 8 . 3 3 \%} \\ \text { Both (laptop and } & 8 & 13.33 \% \\ \text { desktop) } & & 5 & 8.33 \%\end{array}$

Placing of computer

while working

Table

$\begin{array}{lll}\text { Bed } & 36 & \mathbf{6 0 \%}\end{array}$

$18 \quad 30 \%$

$\begin{array}{lll}\text { Other place } & 6 & 10 \%\end{array}$

Whether help from

others personnel is

sought for submitting

the computerized

Assignment in time

Yes

No

$\begin{array}{ll}15 & 25 \\ 45 & \mathbf{7 5}\end{array}$

The data presented in table 1 showed that majority of the students $(44 ; 73.33 \%)$ belonged to the age group of 24-34 years, $50(83.33 \%)$ had not undergone an computer courses, 39(65\%) used computer for more than 5 days per week, 32(53.33\%) used computer for 2-4 hrs per day, 53(88.33\%) heard about computer related hazards from other sources, $47(78.33 \%)$ were using laptop, $36(60 \%)$ were lacing computer on the table while working, $45(75 \%)$ had not sought for help from others for submitting the computerized assignment in time.

section II: findings related to the assessment of computer related ergonomic practices

$\mathrm{n}=60$ 


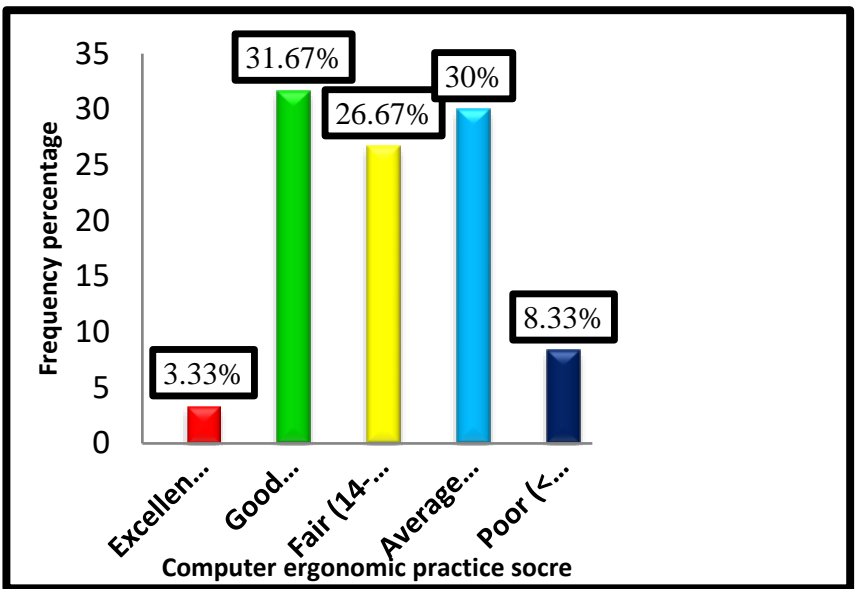

Maximum possible score $=22$; Minimum possible score $=0$

Figure 1: Bar diagram showing distribution of sample according to the computer related ergonomic practice score

The data presented in figure 1showed that $(19 ; 31.67 \%)$ of the students had "good" practice, 18(30\%) had "average", $16(26.67 \%)$ had "fair", $5(8.33 \%)$ had "poor" and 2(3.33\%) had "excellent" practice score of computer related ergonomic practice.

Table 2 mean median and standard deviation of computer related ergonomic practices among final year postgraduate nursing

$$
\begin{gathered}
\text { students } \\
n=60
\end{gathered}
$$

\begin{tabular}{|l|l|l|l|}
\hline & Mean & Median & $\begin{array}{l}\text { Standard } \\
\text { deviation }\end{array}$ \\
\hline $\begin{array}{l}\text { Computer } \\
\text { related } \\
\text { ergonomic } \\
\text { practices }\end{array}$ & 14.4 & 15 & 2.59 \\
\hline
\end{tabular}

Maximum possible: 22 Minimum possible : 0

Data presented in table 2 showed that the mean of computer related ergonomic practice score was 14.4, median 15 and standard deviation 2.59 .

Section III findings related to assessment of computer related health problems among the final year postgraduate nursing students

Table 3 frequency and percentage distribution of final year postgraduate nursing students according to domain wise (musculoskeletal, skin, eye) computer related health problems $\mathrm{n}=60$

\begin{tabular}{|l|l|l|l|l|l|}
\hline Problem & Degree & Range & $\begin{array}{l}\text { Maxim } \\
\text { um } \\
\text { score: } \\
\text { Minimu } \\
\text { m } \\
\text { score: }\end{array}$ & $\begin{array}{l}\text { Fre } \\
\text { que }\end{array}$ & $\%$ \\
ncy & & \\
& & & & \\
\hline
\end{tabular}

\begin{tabular}{|l|l|l|l|l|l|}
\hline Musculosk & Mild & $12-20$ & 36 & 19 & 31. \\
eletal & Moderat & $21-28$ & 12 & 39 & 67 \\
& e to 12 & $29-36$ & & 2 & 65 \\
& Severe & & & & 3.3 \\
& & & & & 3 \\
\hline Skin & Mild & $2-4$ & 6 & 58 & 96. \\
Q13 to 14 & Moderat & $5-6$ & 2 & 2 & 67 \\
& e & & & & 3.3 \\
& & & & & 3 \\
\hline Eye & Mild & $8-13$ & 24 & 19 & 31. \\
Q15 to 22 & Moderat & $14-19$ & 12 & 37 & 66 \\
& e & $20-25$ & & 4 & 61. \\
& Severe & & & & 6 \\
& & & & & 6.6 \\
& & & & & 7 \\
\hline
\end{tabular}

Data presented in table 3 showed that majority $39(65 \%)$ had moderate musculoskeletal problem, 58(96.67\%) had been affected with mild skin problem, 39(61.6\%) had developed moderate eye problem

Table 4 Mean, median and standard deviation of computer related health problems scores among final year postgraduate nursing students

$$
\mathrm{n}=60
$$

\begin{tabular}{|l|l|l|l|}
\hline Variable & Mean & Median & $\begin{array}{l}\text { Standard } \\
\text { deviation }\end{array}$ \\
\hline $\begin{array}{l}\text { Computer } \\
\text { related health } \\
\text { problems }\end{array}$ & 39.3 & 39 & 5.47 \\
\hline
\end{tabular}

Maximum possible $66 \quad$ Minimum possible : 22

Data presented in table 4 showed that the mean of computer related health problem score among the students was 39.3 with a standard deviation of 5.47 and the median was 39 .

Section IV: Correlation coefficients between computer related ergonomic practices and computer related health problem

Table 5 Correlation coefficient and its significance existing between computer related ergonomic practices and computer related health problem among the final year postgraduate nursing students $\mathbf{n}=\mathbf{6 0}$

\begin{tabular}{|l|l|l|l|}
\hline Variable & $\begin{array}{l}\text { Correlation } \\
(\mathrm{r})\end{array}$ & t-score & Significant \\
\hline $\begin{array}{l}\text { Computer } \\
\text { related } \\
\text { ergonomic } \\
\text { practices }\end{array}$ & -0.14 & 1.11 & Not significant \\
$\begin{array}{l}\text { Computer } \\
\text { related health } \\
\text { problems }\end{array}$ & & \\
\hline
\end{tabular}

Data presented in the table 5could not explore statistically significant relationship between computer related ergonomic practices and computer related health problem among the students 
at 0.05 level of significance as evident from the corresponding tvalue.

It could be concluded from the above table that the health problems experienced by the students of the present study were not dependent upon the ergonomics practices.

Table 6 Correlation coefficient and its significance existing between computer related ergonomic practices and computer related health problem (domain wise) among the final year postgraduate nursing students $\mathrm{n}=60$

\begin{tabular}{|l|l|l|l|}
\hline $\begin{array}{l}\text { Computer related } \\
\text { ergonomic } \\
\text { practices }\end{array}$ & $\begin{array}{l}\text { Correlation } \\
(\mathrm{r})\end{array}$ & t-score & Significant \\
\hline Musculoskeletal & -0.098 & 0.75 & NS \\
Skin & -0.14 & 1.16 & NS \\
Eye & -0.09 & 0.76 & NS \\
\hline
\end{tabular}

Data resented in the table 6 could not explore statistically significant relationship between computer related ergonomic practices and domain wise computer related health problems among the students at 0.05 level of significance as evident from the corresponding t-value.

It could be concluded from the above table that the musculoskeletal, skin and eye problems experienced by the students of the resent study were not dependent upon the computer related ergonomics practices

Section V: Association between the computer related ergonomic practices and selected demographic variable among final year post graduate nursing students

\section{Table 7 Chi-square test of association between computer related ergonomic practices and their age. $n=60$}

\begin{tabular}{|l|l|l|l|l|l|}
\hline $\begin{array}{l}\text { Age } \\
\text { (in } \\
\text { years) }\end{array}$ & \multicolumn{2}{|l|}{$\begin{array}{l}\text { Computer } \\
\text { ergonomic practice score }\end{array}$} & $\begin{array}{l}\text { Chi- } \\
\text { square } \\
\text { value }\end{array}$ & Significance \\
\hline & $<$ & $\begin{array}{l}\geq \\
\text { Median }\end{array}$ & Total & & \\
& Median & & & \\
\hline$<35$ & 23 & 21 & 44 & 1.025 & NS \\
$\geq 35$ & 6 & 10 & 16 & & \\
Total & 29 & 31 & 60 & & \\
\hline
\end{tabular}

$\chi^{2} \operatorname{df}(1)=3.84 ; p<0.05$

Data presented in table 7 showed that out of 44 students, with less than 35 years of age 23 scored below median and 21 scored at and above median of the total ergonomic practice score. Similarly, out of 16 students, with more than 35 years of age 6 scored below median and 10 scored at and above median of the total ergonomic practice score.

Chi square value was computed to see the association between the two variables which was found not to be statistically significant at 0.05 level of significance. So, it could be concluded that the computer related ergonomic practice among the students of the present study was independent of their age.
Table 8 Chi-square of association between computer related ergonomic practices and the type of computer device used by the final year postgraduate nursing students. $\mathrm{n}=\mathbf{6 0}$

\begin{tabular}{|c|c|c|c|c|c|}
\hline \multirow{2}{*}{$\begin{array}{l}\text { Type of } \\
\text { compute } \\
\mathrm{r} \text { device } \\
\text { used }\end{array}$} & \multicolumn{3}{|c|}{$\begin{array}{l}\text { Computer ergonomic } \\
\text { practice score }\end{array}$} & \multirow{2}{*}{$\begin{array}{l}\text { Chi } \\
\text { squa } \\
\text { re } \\
\text { valu } \\
\text { e }\end{array}$} & \multirow[t]{2}{*}{ Significance } \\
\hline & $\begin{array}{l}< \\
\text { Media } \\
\mathrm{n}\end{array}$ & $\begin{array}{l}\geq \text { Medi } \\
\text { an }\end{array}$ & $\begin{array}{l}\text { Tot } \\
\text { al }\end{array}$ & & \\
\hline $\begin{array}{l}\text { Laptop } \\
\text { Desktop } \\
\text { Both } \\
\text { Total }\end{array}$ & $\begin{array}{l}22 \\
3 \\
4 \\
29\end{array}$ & $\begin{array}{l}25 \\
5 \\
1 \\
31\end{array}$ & $\begin{array}{l}45 \\
8 \\
5 \\
60\end{array}$ & 2.74 & NS \\
\hline
\end{tabular}

Yate's correction considered

$\chi^{2} \operatorname{df}(2)=5.99 ; \mathrm{p}<0.05$

Data presented in table 8 showed that out of 45 students, who used laptop, 22 had scored below median and 25 had score at and above median of the total ergonomic practice score. Again among 8 students, who used desktop, 3 scored below median and 5 scored at and above median of the total ergonomic practice score. Similarly, among 5 students, who used both (laptop \& desktop), 4 had scored below median and 1 had scored at and above median of total ergonomic practice score.

Chi square value was computed to see the association between two variables which was found not to be significant at 0.05 level of significance. So, it can be concluded that the computer related ergonomic practice score among the nursing student of the present study was independent with their type of computer device used.

Section VI: Association between the computer related health problem and selected demographic variable among final year postgraduate nursing students

\section{Table 9 Chi-square of association between computer related health problems and their age $\mathbf{n}=\mathbf{6 0}$}

\begin{tabular}{|c|c|c|c|c|c|}
\hline \multirow{2}{*}{$\begin{array}{l}\text { Age } \\
\text { (in } \\
\text { years) }\end{array}$} & \multicolumn{3}{|c|}{$\begin{array}{l}\text { Computer related health } \\
\text { problem score }\end{array}$} & \multirow{2}{*}{$\begin{array}{l}\text { Chi } \\
\text { square } \\
\text { value }\end{array}$} & \multirow[t]{2}{*}{ Significance } \\
\hline & $\begin{array}{l}< \\
\text { Median }\end{array}$ & $\begin{array}{l}\geq \\
\text { Median }\end{array}$ & Total & & \\
\hline $\begin{array}{l}<35 \\
\geq 35 \\
\text { Total }\end{array}$ & $\begin{array}{l}19 \\
9 \\
28\end{array}$ & $\begin{array}{l}25 \\
7 \\
32\end{array}$ & $\begin{array}{l}44 \\
16 \\
60\end{array}$ & 0.805 & $\begin{array}{l}\text { Not } \\
\text { significant }\end{array}$ \\
\hline
\end{tabular}

$\chi^{2} \operatorname{df}(1)=3.84 ; \mathrm{p}<0.05$

Data presented in table 9 showed that out of 44 students, with less than 35 years of age 19 scored below median and 25 scored at and above median of the total computer related health problems score. Similarly, out of 16 students, at or above 35 years of age, 9 scored below median and 7 scored at and above median of the total computer related health problems score.

Chi square value was computed to see the association between two variables which was found not to be significant at 0.05 level of significance. So it could be concluded that the computer related 
health problem among the nursing student of the present study was independent of their age.

Table 10 Chi-square of association between computer related health problem and number of days in a week. $\mathbf{n}=60$

\begin{tabular}{|c|c|c|c|c|c|}
\hline \multirow{2}{*}{$\begin{array}{l}\text { Numbe } \\
\text { r of } \\
\text { days } \\
\text { per } \\
\text { week }\end{array}$} & \multicolumn{3}{|c|}{$\begin{array}{l}\text { Computer related health } \\
\text { problem score }\end{array}$} & \multirow{2}{*}{$\begin{array}{l}\text { Chi } \\
\text { squar } \\
\mathrm{e} \\
\text { value }\end{array}$} & \multirow[t]{2}{*}{$\begin{array}{l}\text { Significanc } \\
\mathrm{e}\end{array}$} \\
\hline & $\begin{array}{l}<\text { Media } \\
\mathrm{n}\end{array}$ & $\begin{array}{l}\geq \text { Media } \\
\mathrm{n}\end{array}$ & $\begin{array}{l}\text { Tota } \\
1\end{array}$ & & \\
\hline $\begin{array}{l}<5 \\
\geq 5 \\
\text { Total }\end{array}$ & $\begin{array}{l}12 \\
16 \\
28\end{array}$ & $\begin{array}{l}9 \\
23 \\
32\end{array}$ & $\begin{array}{l}21 \\
39 \\
60\end{array}$ & 1.42 & $\begin{array}{l}\text { Not } \\
\text { significant }\end{array}$ \\
\hline
\end{tabular}

$\chi^{2} \operatorname{df}(1)=3.84 ; \mathrm{p}<0.05$

Data presented in table 10 showed that out of 21 students, who used computer on less than 5 days per week, 12 had scored below median and 9 had score at and above median of the total computer related health problems score. Similarly, among 39 students, who were used to use computer on 5 days or more in a week, 16 scored below median and 23 scored at and above median of the total computer related health problems score.

Chi square value was computed to see the association between two variables which was found not to be significant at 0.05 level of significance. So, it could be concluded that computer related health problem score among the students of the present study were independent of the days they were spending on computers per week.

Table 11 Chi-square of association between computer related health problems and type of computer device used among the final year postgraduate nursing student. $\mathbf{n}=\mathbf{6 0}$

\begin{tabular}{|c|c|c|c|c|c|}
\hline \multirow{2}{*}{$\begin{array}{l}\text { Type of } \\
\text { computer } \\
\text { device used }\end{array}$} & \multicolumn{3}{|c|}{$\begin{array}{l}\text { Computer related health } \\
\text { problem score }\end{array}$} & \multirow{2}{*}{$\begin{array}{l}\text { Chi } \\
\text { square } \\
\text { value }\end{array}$} & \multirow[t]{2}{*}{$\begin{array}{l}\text { Signific } \\
\text { ance }\end{array}$} \\
\hline & $\begin{array}{l}<\mathrm{m} \\
\text { edi } \\
\text { an }\end{array}$ & $\begin{array}{l}\geq \text { me } \\
\text { dian }\end{array}$ & total & & \\
\hline $\begin{array}{l}\text { Laptop } \\
\text { Desktop } \\
\text { Both } \\
\text { Total }\end{array}$ & $\begin{array}{l}18 \\
6 \\
4 \\
28 \\
\end{array}$ & $\begin{array}{l}29 \\
2 \\
1 \\
32\end{array}$ & $\begin{array}{l}47 \\
8 \\
5 \\
60 \\
\end{array}$ & 6.333 & $\mathrm{~S}$ \\
\hline
\end{tabular}

Yate's correction considered $\chi^{2} \mathrm{df}(2)=5.99 ; \mathrm{p}<0.05$

Data presented in table 11 showed that out of 47 students, who used laptop, 18 had scored below median and 29 had score at and above median of the total computer related health problem score. Again among 8 students, who used desktop, 6 scored below median and 2 scored at and above median of the total computer related health problem score. Similarly, among 5 students, who used both (laptop \& desktop), 4 had scored below median and 1 had scored at and above median of total computer related health problem score.

Chi square value was computed to see the association between two variables which was found to be significant at 0.05 level of significance. So, it could be concluded that computer related health problem among the nursing students of the present study was dependent with the type of the computer device used. It appears that relatively uses of laptop among the final year postgraduate nursing student is more than other computer device.

\section{CONCLUSION}

1. From the study findings it can be concluded that majority of the students had good compliance with computer related ergonomic practices.

2. There were three main areas in the questionnaire to assess the occurrence of computer-related health problem viz. musculoskeletal, skin and eye problems. out of thee three areas, the problem related to musculoskeletal and eye was more than skin problems. The magnitude of the problems was moderate.

3. Computer related health problemswere dependent on average total hours spent on computer per day and type of computer device used.

\section{REFERENCES}

[1] Helander Martin, A Guide to Human Factors and Ergonomics, 2nd edition, Taylor \& Francis group, 2006, page no. 3. Available from: http://www.books.google.co.in/books?id=pJvSnAMIZ_gC\&printsec=frontc over\&dq=inauthor.html.

[2] "Ergonomics for Computer use". Asian Transactions on Science \& Technology (ATST ISSN: 2221-4283) Volume 01 Issue 06. Jan 2012 . Available from: http://www.asiantransactions.org/ATSTVol01Issue06.htm.

[3] Carter JB, Banister EW. Musculoskeletal problems among computer users: a review. Ergonomic 1994; 37: 1623-1648, Pmid: 7957019. Available from : http://www.ncbi.nlm.nih.gov/pubmed/7957019 .

[4] Kanchanomai S, Janwantanakul P, Pensri P, Jiamjarasrangsi W. A study on the Risk factors for the onset and persistence of neck pain in undergraduate students: 1-year prospective cohort study. BMC Public Health Journal. 2011 Jul 15;11:566. doi: 10.1186/1471-2458-11-566. Available from: http://www.ncbi.nlm.nih.gov/pubmed/21756362

\section{AUTHORS}

First Author - Porimita Moran, BSN, MSN, Staff nurse at Oil India limited Hospital, Duliajan, Dibrugarh 
